\title{
Roles of $\mathrm{MgO}$ and $\mathrm{Al}_{2} \mathrm{O}_{3}$ on the Viscous and Structural Behavior of Blast Furnace Primary Slag, Part 1: $\mathrm{C} / \mathrm{S}=1.3$ Containing $\mathrm{TiO}_{2}$
}

\author{
Tingle Li ${ }^{1,2}$, Changyu Sun ${ }^{1,2}$, Sunny Song ${ }^{3}$ and Qi Wang ${ }^{1,2, *(\mathbb{D}}$ \\ 1 Key Laboratory of Chemical Metallurgy Engineering Liaoning Province, \\ University of Science and Technology Liaoning, Anshan 114051, China \\ 2 School of Materials and Metallurgy, University of Science and Technology Liaoning, Anshan 114051, China \\ 3 Technical Marketing, Rio Tinto Iron Ore, Perth 6000, Australia \\ * Correspondence: wangqi8822@sina.com; Tel.: +86-0412-5929557
}

Received: 24 July 2019; Accepted: 6 August 2019; Published: 8 August 2019

\begin{abstract}
This research provides fundamental insight into the roles of $\mathrm{MgO}$ and $\mathrm{Al}_{2} \mathrm{O}_{3}$ on the viscous and structural behaviors of $\mathrm{CaO}-\mathrm{SiO}_{2}-\mathrm{MgO}-\mathrm{Al}_{2} \mathrm{O}_{3}-10$ mass $\% \mathrm{TiO}_{2}-5$ mass $\% \mathrm{FeO}\left(\mathrm{CaO} / \mathrm{SiO}_{2}=1.3\right)$ system primary blast furnace slag. The slag viscosity is measured by the rotating cylinder method, which is essential to the efficient and stable operation of a blast furnace. The network structure characterization of the quenched vitreous samples was conducted using Fourier Transformation Infrared (FTIR) and Raman spectroscopy. Usual viscous behaviors (that the slag viscosity and the activation energy decrease or increase with increasing $\mathrm{MgO}$ or $\mathrm{Al}_{2} \mathrm{O}_{3}$ content) were observed, corresponding to changes in the network structure certified by FTIR and Raman analyses. It seems that the addition of $\mathrm{MgO}$ and $\mathrm{Al}_{2} \mathrm{O}_{3}$ prefers to modify the $\mathrm{Si}-\mathrm{O}$ and Ti-O network in the present slag. When the slag composition reaches $10 \% \mathrm{MgO}$ and $12 \% \mathrm{Al}_{2} \mathrm{O}_{3}$, unexpected viscous behaviors (that $\mathrm{MgO}$ increases viscosity and $\mathrm{Al}_{2} \mathrm{O}_{3}$ decreases viscosity) are discovered. The roles of $\mathrm{MgO}$ and $\mathrm{Al}_{2} \mathrm{O}_{3}$ could be interpreted by changes in the arrangement structure of ions in liquid, corresponding to changes in the primary equilibrium phase region determined in phase diagrams and variation in the difference between the experimental and liquidus temperature, respectively.
\end{abstract}

Keywords: Ti-bearing primary slag; $\mathrm{MgO} ; \mathrm{Al}_{2} \mathrm{O}_{3}$; viscosity; activation energy; network structure

\section{Introduction}

Iron ore containing $\mathrm{TiO}_{2}$ is widely used in many blast furnaces $(\mathrm{BFs})$ to produce hot metal in China because of the country's big reserves of titanium magnetite ore. In the last few years, the steel industry has faced significant challenges from iron resources and environment-energy saving restrictions [1]. High alumina iron ore has been considered due to its low cost [2]. The reasonable combination of high aluminum ore and titanium magnetite ore is an economical choice for Ti-bearing iron ore smelting. Meanwhile, high smelting efficiency and low emissions need to be ensured. Under such a background, the $\mathrm{Al}_{2} \mathrm{O}_{3}$ content in $\mathrm{BF}$ Ti-bearing slag is inevitably increased. $\mathrm{MgO}$ is one of the main components of $\mathrm{BF}$ slag and is suggested to be able to effectively adjust metallurgical properties.

Slag viscosity is one of the most important physicochemical properties in determining solid-liquid reactions, gas distribution (permeability), and smooth running, which all affect high quality smelting. In the BF smelting process with a Ti-bearing burden, the primary slag forms in the softening-melting zone (in terms of slag formation behavior). Through a series of transitions, the primary slag turns into the final slag, which stably exists in the $\mathrm{BF}$ hearth. The final slag is usually described by a $\mathrm{CaO}-\mathrm{MgO}-\mathrm{Al}_{2} \mathrm{O}_{3}-\mathrm{SiO}_{2}-\mathrm{TiO}_{2}$ quinary system, which has been researched in many experimental 
studies [3-9] about the effects of $\mathrm{MgO}$ and $\mathrm{Al}_{2} \mathrm{O}_{3}$ on slag viscosity. The effect of $\mathrm{Al}_{2} \mathrm{O}_{3}$ content on the viscosity of quinary slag with different $\mathrm{TiO}_{2}$ concentrations was studied by Feng et al. [3], Yan et al. [4], and Bian and Gao [5]. All the results showed that $\mathrm{Al}_{2} \mathrm{O}_{3}$ increased viscosity, which was attributed to the role of $\mathrm{Al}_{2} \mathrm{O}_{3}$ in the polymerization of silicate melts [10,11]. Zhou et al. [6] held another viewpoint - that the effect of $\mathrm{Al}_{2} \mathrm{O}_{3}$ was dependent on the composition of slag. As for the effect of $\mathrm{MgO}$, several researchers have reported that slag viscosity exhibited a decreasing trend with increasing $\mathrm{MgO}$ content [4,7-9], which was partially different to the change of the activation energy. It was found by Feng et al. [7] that the activation energy first increased and then decreased with an increase of $\mathrm{MgO}$, while it was reported by Liang et al. [8] that $\mathrm{MgO}$ contributed an opposite tendency to the activation energy. However, plenty of the work focusing on the final slag may be not suitable for expounding the issues in a high temperature BF process with a Ti-bearing burden, such as the poor slag/iron separation and unstable permeability [12]. Although these issues are closely related to the primary slag, the experimental viscosity data are scarce because the primary slag cannot be visible and directly removed. This is disadvantageous for understanding and controlling the actual production. Therefore, the viscous behaviors of the Ti-bearing primary slag are arousing interest.

Combined with the current development of raw iron ore materials, the $\mathrm{CaO}-\mathrm{SiO}_{2}-\mathrm{MgO}-\mathrm{Al}_{2} \mathrm{O}_{3}-\mathrm{TiO}_{2}-\mathrm{FeO}$ multi-component system slag with varying $\mathrm{MgO}$ and $\mathrm{Al}_{2} \mathrm{O}_{3}$ content is designed to simulate Ti-bearing primary slag for viscosity measurement. Meanwhile, Fourier Transformation Infrared (FTIR) and Raman spectroscopy are used to illustrate changes in the network structure corresponding to the variations in viscosity. This study will develop a better understanding of Ti-bearing slag from a broader perspective.

\section{Experimental Samples and Procedure}

\subsection{Starting Materials}

The chemical compositions of slag samples are given in Table 1 . The variables represent the $\mathrm{MgO}$ and $\mathrm{Al}_{2} \mathrm{O}_{3}$ content, which change from 8 to 12 mass $\%$ and 10 to 18 mass $\%$ at a fixed $\mathrm{CaO} / \mathrm{SiO}_{2}$ of 1.3 (binary basicity, abbreviated as $\mathrm{C} / \mathrm{S}$ ), with a $\mathrm{FeO}$ content of 5 mass $\%$ and a $\mathrm{TiO}_{2}$ content of 10 mass $\%$, respectively. The starting materials for the viscosity experiments consist of $\mathrm{FeC}_{2} \mathrm{O}_{4} \cdot 2 \mathrm{H}_{2} \mathrm{O}, \mathrm{CaCO}_{3}$, $\mathrm{SiO}_{2}, \mathrm{MgO}, \mathrm{Al}_{2} \mathrm{O}_{3}$, and $\mathrm{TiO}_{2}$ powder with analytical purity. $\mathrm{FeC}_{2} \mathrm{O}_{4} \cdot 2 \mathrm{H}_{2} \mathrm{O}$ and $\mathrm{CaCO}_{3}$ are used for producing $\mathrm{CaO}$ and $\mathrm{FeO}$, respectively.

Table 1. The chemical compositions of the designed Ti-bearing primary slags (mass $\%$ ).

\begin{tabular}{cccccccc}
\hline \multirow{2}{*}{ Slags } & $\mathbf{C a O}$ & $\mathbf{S i O}_{\mathbf{2}}$ & $\mathbf{M g O}$ & $\mathbf{A l}_{\mathbf{2}} \mathbf{O}_{\mathbf{3}}$ & $\mathbf{T i O}_{\mathbf{2}}$ & $\mathbf{F e O}$ & $\begin{array}{c}\text { Analyzed } \\
\text { FeO }\end{array}$ \\
\hline $\mathrm{A1}^{\mathrm{a}}$ & 37.87 & 29.13 & 8.00 & 10.00 & 10.00 & 5.00 & 4.62 \\
$\mathrm{~A} 2$ & 36.74 & 28.26 & 10.00 & 10.00 & 10.00 & 5.00 & 4.86 \\
$\mathrm{~A} 3$ & 35.61 & 27.39 & 12.00 & 10.00 & 10.00 & 5.00 & 4.69 \\
$\mathrm{~B}{ }^{\mathrm{a}}$ & 36.74 & 28.26 & 8.00 & 12.00 & 10.00 & 5.00 & 4.43 \\
$\mathrm{~B} 2$ & 35.61 & 27.39 & 10.00 & 12.00 & 10.00 & 5.00 & 4.71 \\
$\mathrm{~B} 3$ & 34.48 & 26.52 & 12.00 & 12.00 & 10.00 & 5.00 & 4.68 \\
$\mathrm{C1}^{\mathrm{a}}$ & 35.04 & 26.96 & 8.00 & 15.00 & 10.00 & 5.00 & 4.71 \\
$\mathrm{C} 2$ & 33.91 & 26.09 & 10.00 & 15.00 & 10.00 & 5.00 & 4.54 \\
$\mathrm{C} 3$ & 32.78 & 25.22 & 12.00 & 15.00 & 10.00 & 5.00 & 4.60 \\
$\mathrm{D} 1^{\mathrm{a}}$ & 33.35 & 25.65 & 8.00 & 18.00 & 10.00 & 5.00 & 4.57 \\
$\mathrm{D} 2$ & 32.22 & 24.78 & 10.00 & 18.00 & 10.00 & 5.00 & 4.66 \\
$\mathrm{D} 3$ & 31.09 & 23.91 & 12.00 & 18.00 & 10.00 & 5.00 & 4.55 \\
\hline
\end{tabular}

${ }^{a}$ Data from our previous work [13] are provided here for comparison. 


\subsection{Experimental Methods}

The experimental apparatus (RTW-10, Northeastern University, Shenyang, China) for viscosity measurement, as shown in Figure 1, mainly consists of a viscometer, heating units, water cooling, and a gas system. The Mo crucible with an inner diameter of $40 \mathrm{~mm}$ and depth of $80 \mathrm{~mm}$ was selected to be the slag container. To avoid oxidation of $\mathrm{FeO}$, the $\mathrm{Mo}$ crucible was put into a graphite crucible. High purity Ar gas $(0.5 \mathrm{~L} / \mathrm{min})$ was blown into the $\mathrm{Al}_{2} \mathrm{O}_{3}$ tube at the beginning of the rising temperature. Before the experiment, the Mo crucible and spindle with the same sizes for slag viscosity measurement were employed to calibrate the viscometer using castor oil with known viscosities $(0.986$, 0.651 , and $0.451 \mathrm{~Pa} \cdot \mathrm{s}$ ) at different room temperatures. A certain amount of castor oil filled the Mo crucible with a depth of $40 \mathrm{~mm}$, which is approximately equal to the depth of the slag during the viscosity measurement.

The chemical powders comprising $\mathrm{CaO}-\mathrm{SiO}_{2}-\mathrm{MgO}-\mathrm{Al}_{2} \mathrm{O}_{3}-10$ mass $\% \mathrm{TiO}_{2}-5$ mass $\%$ FeO slag of $140 \mathrm{~g}$ were weighed separately after being dried. The five chemicals, $\mathrm{CaCO}_{3}, \mathrm{SiO}_{2}, \mathrm{MgO}_{1} \mathrm{Al}_{2} \mathrm{O}_{3}$, and $\mathrm{TiO}_{2}$, were mixed in a ball mill. The mixtures were made into pellets and dried for later use. When the experiment started, the $\mathrm{FeC}_{2} \mathrm{O}_{4} \cdot 2 \mathrm{H}_{2} \mathrm{O}$ powder was first put into the Mo crucible. As the temperature increased, the $\mathrm{FeC}_{2} \mathrm{O}_{4} \cdot 2 \mathrm{H}_{2} \mathrm{O}$ gradually decomposed, softened, and melted. When the $\mathrm{FeC}_{2} \mathrm{O}_{4} \cdot 2 \mathrm{H}_{2} \mathrm{O}$ was observed to be semi-melting, the pellets made above were carefully introduced into the Mo crucible. Similarly, the $\mathrm{CaCO}_{3}$ was also decomposed during the heating process. A high temperature of $1823 \mathrm{~K}$ was finally obtained, which melted the FeO together with other oxides to form the designed slag. The temperature stayed at $1823 \mathrm{~K}$ for $3 \mathrm{~h}$, to ensure slag homogeneity, and then decreased to $1773 \mathrm{~K}$, at which the Mo spindle was immersed into the molten slag $(\sim 40 \mathrm{~mm})$ and positioned $10 \mathrm{~mm}$ away from the bottom of the slag layer. The slag was stirred by the spindle for $30 \mathrm{~min}$, after which the viscosity measurement began. The viscosity measurement was carried out on a cooling style at $25 \mathrm{~K}$ intervals with equilibrium periods of $25 \mathrm{~min}$ for every temperature point. After completing the viscosity measurement, the slag sample was reheated to $1773 \mathrm{~K}$ and kept for $60 \mathrm{~min}$. The slag was subsequently poured into the water quickly. The water quenched slag was collected for chemical composition analyses, and the next sample was prepared for structural investigation. The FeO content in each slag was analyzed by the titration method. The contents of $\mathrm{CaO}$, $\mathrm{SiO}_{2}, \mathrm{MgO}, \mathrm{Al}_{2} \mathrm{O}_{3}$, and $\mathrm{TiO}_{2}$ in $\mathrm{A} 1$ and B1 were determined using X-Ray Fluorescence (XRF, S8 Tiger, Bruker, Karlsruhe, Germany). The C/S were 1.28 and 1.30 for A1 and B1, respectively. The MgO, $\mathrm{Al}_{2} \mathrm{O}_{3}$, and $\mathrm{TiO}_{2}$ contents varied insignificantly compared to the designed compositions. Table 1 shows the FeO contents after the viscosity experiment. Accordingly, all the FeO contents changed little and stabilized at comparable levels.

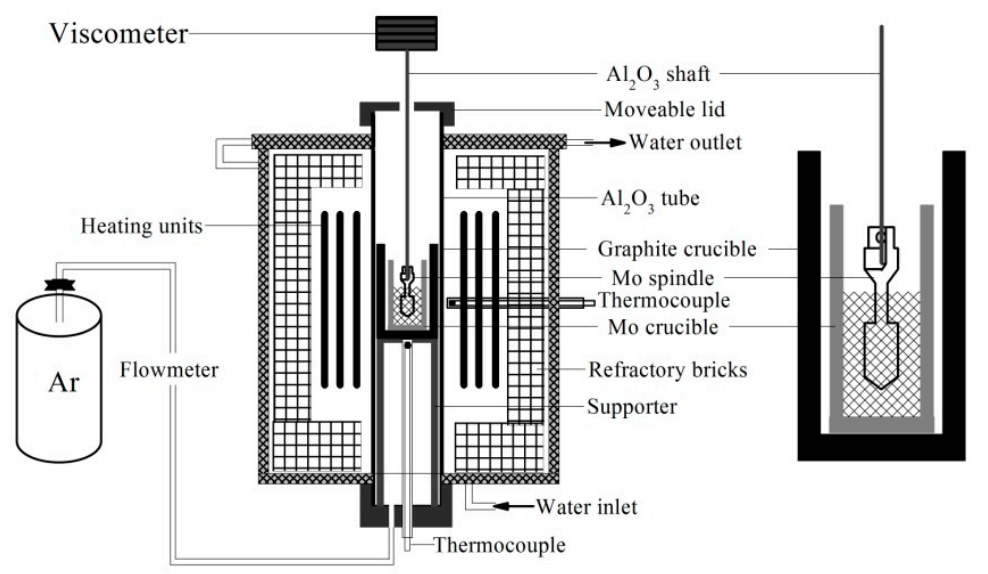

Figure 1. The experimental apparatus for viscosity measurement. 


\subsection{Characterization of the Slag's Network Structure}

The small Mo crucible (formed by punching ( $29 \mathrm{~mm}$ inner diameter, $4.5 \mathrm{~mm}$ depth, and $0.1 \mathrm{~mm}$ thickness)) was selected to re-melt a part of the water quenched slag sample ( 5 g) at $1773 \mathrm{~K}$ for $60 \mathrm{~min}$ under Ar gas protection. Each slag sample was rapidly quenched in water for network structure analysis using XRD (SmartLab SE, Rigaku, Tokyo, Japan), FTIR (Thermo Scientific Nicolet IS5, Nicolet, Madison, WI, USA), and Raman spectroscopy (XploRA PLUS, Horiba Scientific, Edison, NJ, USA).

XRD data collection of the sample was performed with a scanning range of $10-90^{\circ}$ and a time of $10 \mathrm{~min}$ and step size of $0.02^{\circ}$. The operating conditions of the $X$-ray tube were $U=40 \mathrm{kV}$ and $\mathrm{I}=100 \mathrm{~mA}$. The XRD results of the rapidly quenched slag samples are shown in Figure 2, which is evidence that the slag is completely liquid at $1773 \mathrm{~K}$ and maintains an amorphous, high temperature state at room temperature. The FTIR spectrum of the sample was determined by using the potassium bromide (KBr) tablet method [14,15]. The ratio of the sample to KBr was 1:150. Thirty-two scans per spectrum were performed over a range of 4000-400 $\mathrm{cm}^{-1}$. Raman spectroscopy analysis was performed on the samples by using a laser confocal micro-Raman spectrometer. The excitation wavelength of the $\mathrm{Ar}^{+}$laser was $532 \mathrm{~nm}$, and the spectral resolution was $4 \mathrm{~cm}^{-1}$. The recorded spectral range is $100-2000 \mathrm{~cm}^{-1}$.

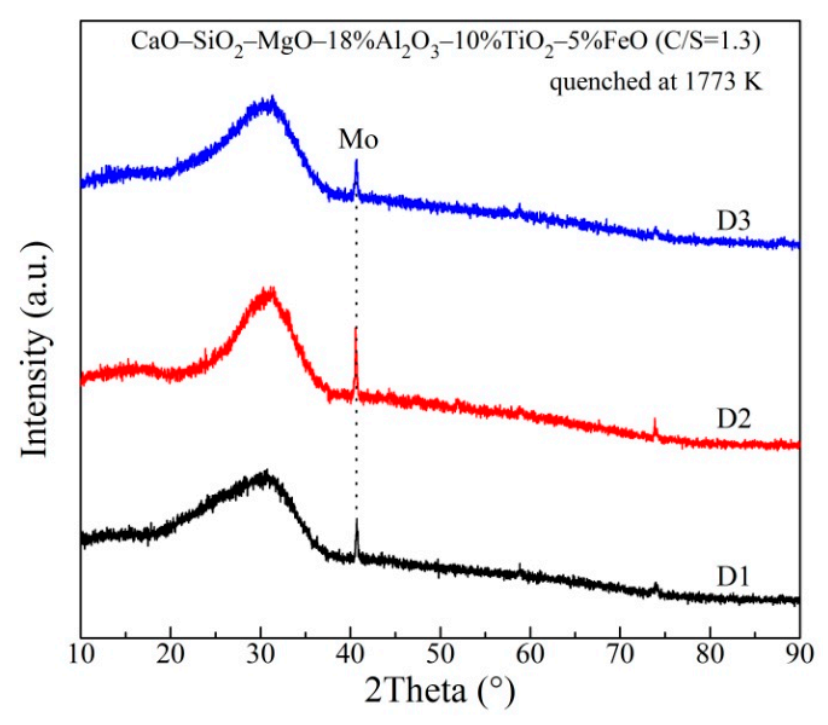

Figure 2. XRD patterns of the rapidly quenched slag samples.

\section{Results}

\subsection{Viscous Behavior with Varying $\mathrm{MgO}$ and $\mathrm{Al}_{2} \mathrm{O}_{3}$}

Figure 3 shows the effect of $\mathrm{MgO}$ content on the viscosity of the slag with different $\mathrm{Al}_{2} \mathrm{O}_{3}$ contents at high temperatures above $1698 \mathrm{~K}$. When the $\mathrm{Al}_{2} \mathrm{O}_{3}$ concentration is $10 \%$ or $18 \%$, the effect of $\mathrm{MgO}$ on viscosity variation is slight in the experimental $\mathrm{MgO}$ range. On the other hand, the viscosity significantly rises once $\mathrm{MgO}$ content is lower than $10 \%$ for the slag with $12 \%$ or $15 \% \mathrm{Al}_{2} \mathrm{O}_{3}$. The trend in the slag viscosity as a function of $\mathrm{MgO}$ content could be regarded as a common pattern of decreasing viscosity with increasing $\mathrm{MgO}$ for slag composed with 10\%, 15\%, and $18 \% \mathrm{Al}_{2} \mathrm{O}_{3}$, whereas the viscosity first decreases and then increases with a higher $\mathrm{MgO}$ for composition with $12 \% \mathrm{Al}_{2} \mathrm{O}_{3}$. According to the viscosity results by $\mathrm{Kim}$ et al. [16], the viscosity of the $\mathrm{CaO}-\mathrm{MgO}-10 \% \mathrm{Al}_{2} \mathrm{O}_{3}-\mathrm{SiO}_{2}-5 \% \mathrm{FeO}(\mathrm{C} / \mathrm{S}=1.35)$ slag slightly decreased with increasing $\mathrm{MgO}$. Liang et al. [8] reported that the $\mathrm{CaO}-\mathrm{MgO}-\mathrm{Al}_{2} \mathrm{O}_{3}-\mathrm{SiO}_{2}-\mathrm{TiO}_{2}$ slag viscosity decreased as $\mathrm{MgO}$ content increased. These results are depicted in Figure $3 \mathrm{a}, \mathrm{b}$ for comparison. It is generally suggested that the slag viscosity decreased as a result of the slag's network structure depolymerization, facilitated by the basic behavior of $\mathrm{MgO}$. However, for the composition with $12 \% \mathrm{Al}_{2} \mathrm{O}_{3}$, the slag viscosity does 
not obey this well-recognized trend. The unusual viscous behavior with changing $\mathrm{MgO}$ (Figure 3b) will be discussed later.

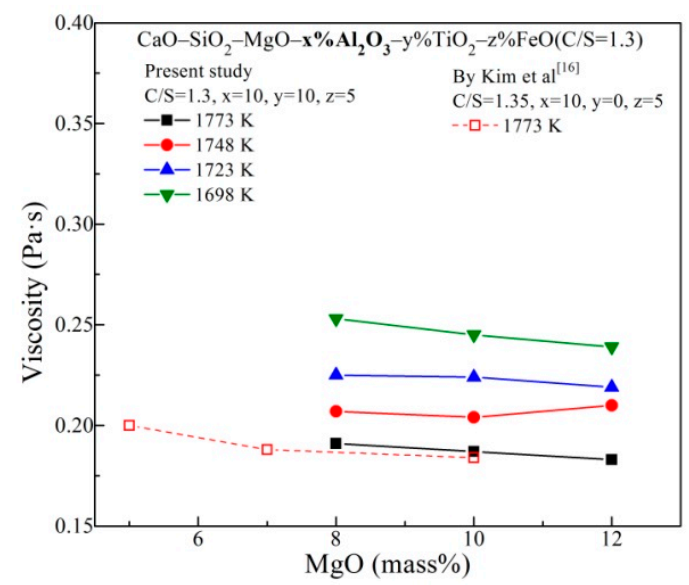

(a)

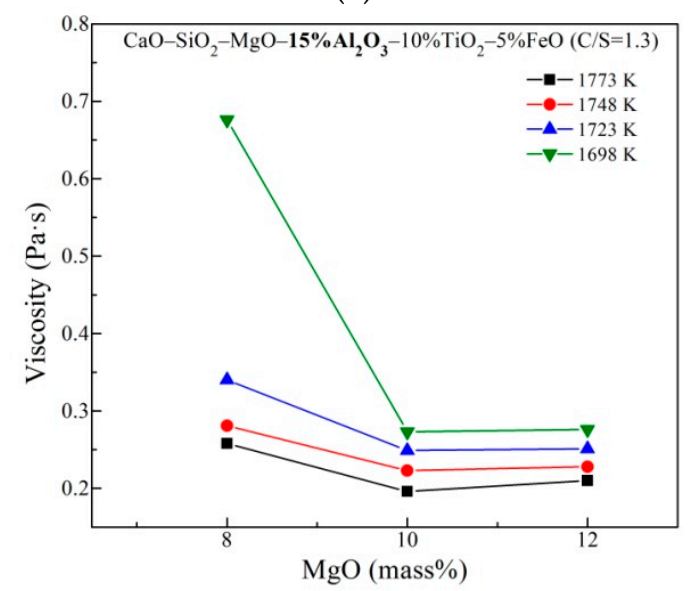

(c)

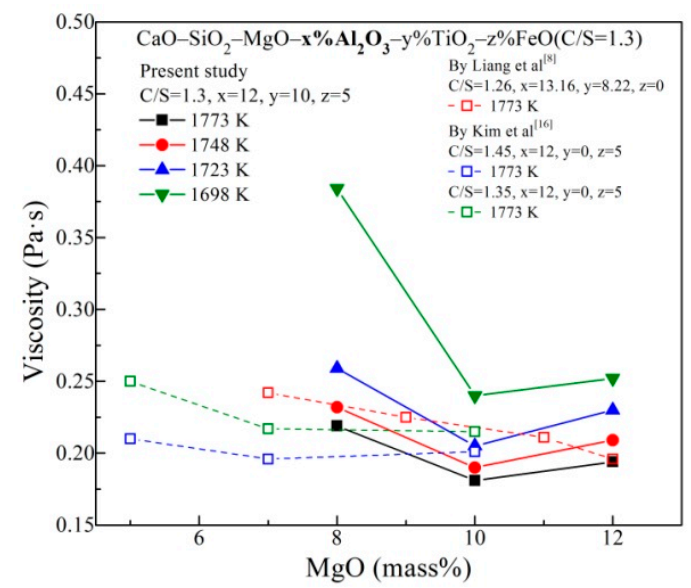

(b)

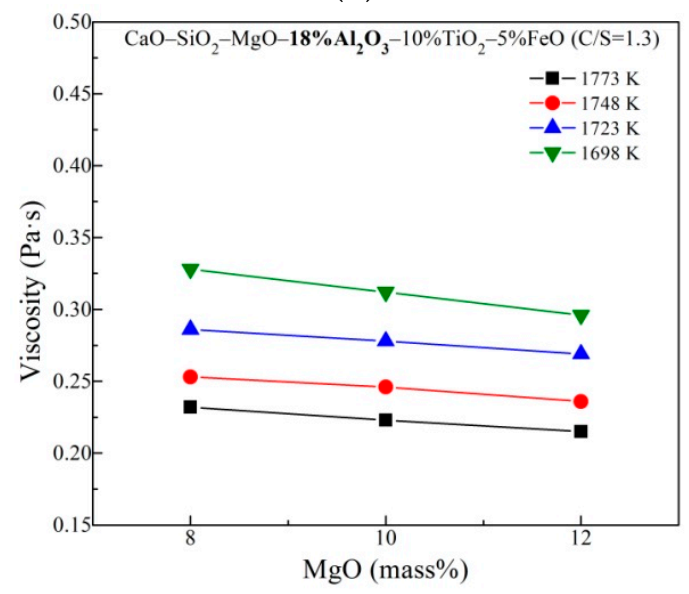

(d)

Figure 3. Effects of $\mathrm{MgO}$ content on the viscosity of slag at various temperatures with (a) 10 mass $\%$ Al2O3, (b) 12 mass $\% \mathrm{Al}_{2} \mathrm{O}_{3}$, (c) 15 mass $\% \mathrm{Al}_{2} \mathrm{O}_{3}$, and (d) 18 mass $\% \mathrm{Al}_{2} \mathrm{O}_{3}$.

The effect of $\mathrm{Al}_{2} \mathrm{O}_{3}$ content on the viscosity of slag with $\mathrm{MgO}$ contents of $10 \%$ and $12 \%$ are shown in Figure 4. The trend of the viscosity as a function of $\mathrm{Al}_{2} \mathrm{O}_{3}$ content exhibited different patterns with increasing $\mathrm{Al}_{2} \mathrm{O}_{3}$ at the studied $\mathrm{MgO}$ concentrations. As noted in our previous work [13], for slag with 8 mass $\% \mathrm{MgO}$, the addition of $\mathrm{Al}_{2} \mathrm{O}_{3}$ with 10 to 15 mass $\%$ increased the viscosity, reaching a maximum, followed by a decrease at higher $\mathrm{Al}_{2} \mathrm{O}_{3}$ content. From Figure $4 \mathrm{a}$, when the slag contains $10 \% \mathrm{MgO}$, by increasing $\mathrm{Al}_{2} \mathrm{O}_{3}$ content from $10 \%$ to $12 \%$, the slag viscosity is reduced. Further increasing $\mathrm{Al}_{2} \mathrm{O}_{3}$ content to $18 \%$ tends to increase the viscosity. On the other hand, the viscosity of the slag with $12 \%$ $\mathrm{MgO}$ monotonically increases with increasing $\mathrm{Al}_{2} \mathrm{O}_{3}$ content, as shown in Figure $4 \mathrm{~b}$. In Feng's study on $\mathrm{CaO}-\mathrm{MgO}-11.32 \% \mathrm{Al}_{2} \mathrm{O}_{3}-\mathrm{SiO}_{2}-6.93 \% \mathrm{TiO}_{2}$ slag, the viscosity increased with the addition of $\mathrm{Al}_{2} \mathrm{O}_{3}$ due to the polymerization of the slag's network structure [3]. The present slag is highly basic because the amount of basic oxides, including $\mathrm{FeO}, \mathrm{CaO}$, and $\mathrm{MgO}$, is higher than 50 mass\%. In such a basic environment, $\mathrm{Al}_{2} \mathrm{O}_{3}$ is likely to demonstrate acid characteristic and polymerize the network structure, such that the effects of $\mathrm{Al}_{2} \mathrm{O}_{3}$ increase viscosity, which is also proposed by Kim et al. [17] and Song et al. [18]. In other words, the increase of viscosity after the addition of $\mathrm{Al}_{2} \mathrm{O}_{3}$ (shown in Figure 4) could be explained by the polymerization of the network structure caused by the acidic behavior of $\mathrm{Al}_{2} \mathrm{O}_{3}$. Nevertheless, the appearance of the minimum viscosity at $10 \% \mathrm{MgO}$ and at $12 \% \mathrm{Al}_{2} \mathrm{O}_{3}$ in Figure $4 \mathrm{a}$ is unusual and will be discussed later. 


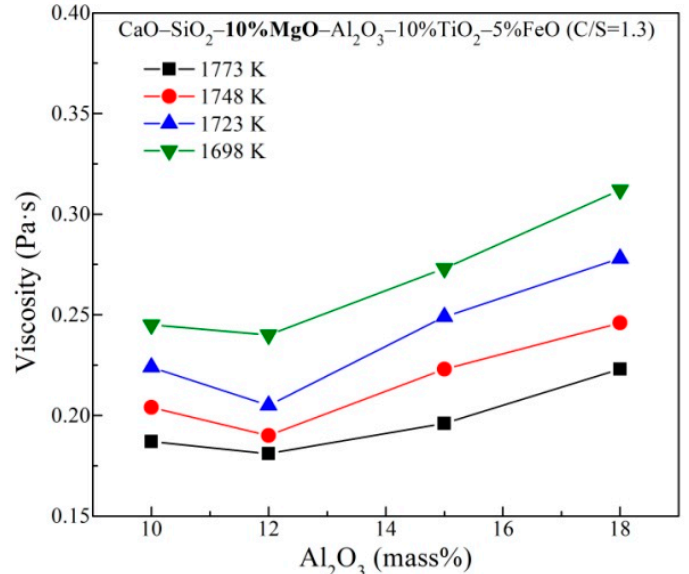

(a)

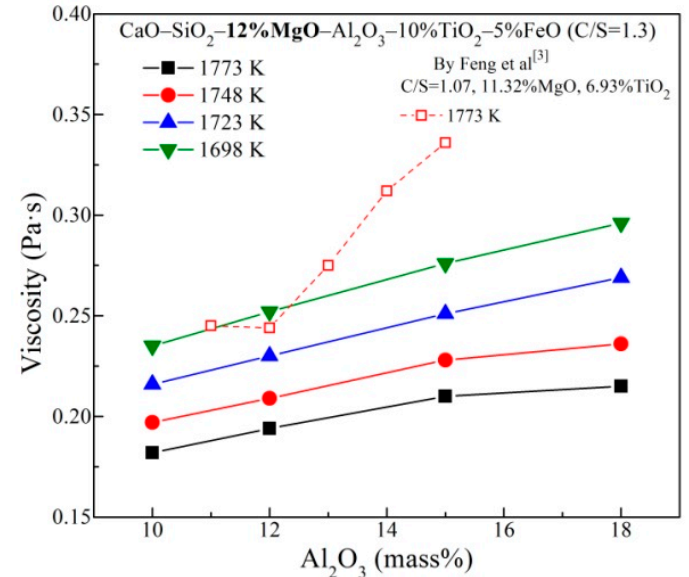

(b)

Figure 4. Effects of $\mathrm{Al}_{2} \mathrm{O}_{3}$ content on the viscosity of slag at various temperatures with (a) 10 mass $\%$ $\mathrm{MgO}$ and (b) 12 mass $\% \mathrm{MgO}$.

The Lnๆ (natural logarithm of the viscosity) should be linear with $1 / T$ (the reciprocal of absolute temperature) at high temperatures, according to the well-known Arrhenius-type relationship [19,20]. The dependence of Ln $\eta$ on $1 / T$ for the slags is depicted in Figure 5 . The $E_{\eta}$ (viscosity activation energy) of slag can be calculated from the linear slope, which is an indication of the frictional resistance of the viscous flow, as listed in Table 2. $E_{\eta}$ is between 63.3 and $140.4 \mathrm{~kJ} / \mathrm{mol}$ and exhibits a common decreasing trend by increasing $\mathrm{MgO}$ content, except for the $12 \% \mathrm{Al}_{2} \mathrm{O}_{3}$ slag. When the slag contains $12 \% \mathrm{Al}_{2} \mathrm{O}_{3}$, a minimum $E_{\eta}$ value of $63.3 \mathrm{~kJ} \cdot \mathrm{mol}^{-1}$ is observed at $10 \% \mathrm{MgO}$. In the case of a fixed $\mathrm{MgO}$ concentration and changing $\mathrm{Al}_{2} \mathrm{O}_{3}$ content, $E_{\eta}$ first decreases and then increases, with a minimum value of $12 \% \mathrm{Al}_{2} \mathrm{O}_{3}$ for $10 \% \mathrm{MgO}$ slag. On the other hand, $E_{\eta}$ continuously increases by increasing $\mathrm{Al}_{2} \mathrm{O}_{3}$ content for $12 \% \mathrm{MgO}$ slag. The variation of $E_{\eta}$ is in agreement with the viscosity results for basically changing $\mathrm{MgO}$ and $\mathrm{Al}_{2} \mathrm{O}_{3}$ content.

The variation of viscosity and $E_{\eta}$ is certainly related to the change of the slag's network structure. In the present slag, the network-forming ions include $\mathrm{Si}^{4+}, \mathrm{Al}^{3+}$, and $\mathrm{Ti}^{4+}$. The specific change of the network structure consisting of $\mathrm{Si}-\mathrm{O}, \mathrm{Al}-\mathrm{O}$, and $\mathrm{Ti}-\mathrm{O}$ network should be clarified using FTIR and Raman spectroscopy to understand the roles of $\mathrm{MgO}$ and $\mathrm{Al}_{2} \mathrm{O}_{3}$.

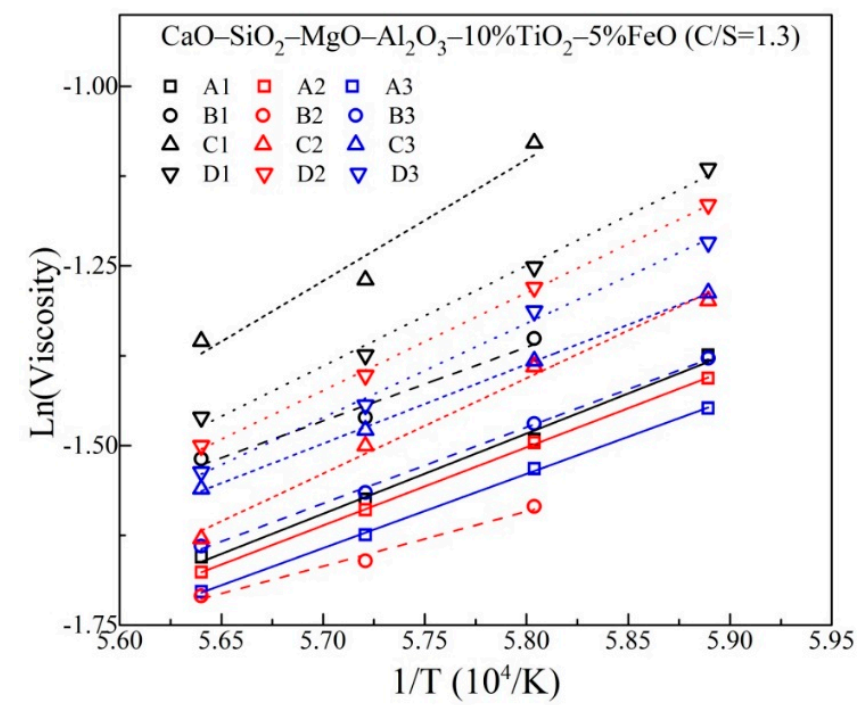

Figure 5. The linear fitting of Lnך to $1 / T$. 
Table 2 . The viscosity activation energy of the slag.

\begin{tabular}{cccc}
\hline Slag & $\mathbf{M g O}(\mathbf{m a s s} \%)$ & $\mathbf{A l}_{\mathbf{2}} \mathbf{O}_{\mathbf{3}}$ (mass\%) & $E_{\boldsymbol{\eta}}(\mathbf{k J} / \mathbf{m o l})$ \\
\hline A1 & 8 & 10 & 92.9 \\
A2 & 10 & 10 & 90.5 \\
A3 & 12 & 10 & 86.0 \\
B1 & 8 & 12 & 85.3 \\
B2 & 10 & 12 & 63.3 \\
B3 & 12 & 12 & 88.2 \\
C1 & 8 & 15 & 140.4 \\
C2 & 10 & 15 & 110.4 \\
C3 & 12 & 15 & 91.7 \\
D1 & 8 & 18 & 116.4 \\
D2 & 10 & 18 & 113.1 \\
D3 & 12 & 18 & 109.1 \\
\hline
\end{tabular}

\subsection{The Network Structure}

The slag samples are first characterized qualitatively using FTIR to identify their network structures. The different types of $\mathrm{Si}-\mathrm{O}$ bonding are correlated with silicate polymerization, as initiated by the work of Stevels $[21,22]$. At present, the $\mathrm{Si}-\mathrm{O}$ network is well known to include four kinds of $\left[\mathrm{SiO}_{4}\right]^{4-}$ tetrahedral units, which have bridging oxygen numbers of 0/1/2/3 with monomer/dimmer/chain/sheet structures; these units are named $\mathrm{Q}^{0}, \mathrm{Q}^{1}, \mathrm{Q}^{2}$, and $\mathrm{Q}^{3}$, respectively. $\mathrm{Al}$ exists in four and six coordinate states [23], corresponding to the $\left[\mathrm{AlO}_{4}\right]^{5-}$ tetrahedral (network former) and $\left[\mathrm{AlO}_{6}\right]^{9-}$ octahedral (network breaker) units. According to former studies on the FTIR of metallurgical slag [14,16,24], the FTIR curve in a wavenumber region of $1200 \sim 750 \mathrm{~cm}^{-1}$ represented the convolution of $\mathrm{Q}^{0}, \mathrm{Q}^{1}, \mathrm{Q}^{2}$, and $\mathrm{Q}^{3}$ structural units, which exhibited characteristic peaks at $\sim 850, \sim 940, \sim 980$, and $\sim 1030 \mathrm{~cm}^{-1}$, respectively. The trough between 750 and $630 \mathrm{~cm}^{-1}$ was the asymmetric characteristic stretching vibration band for the $\left[\mathrm{AlO}_{4}\right]^{5-}$ tetrahedral structure. The peak at $\sim 500 \mathrm{~cm}^{-1}$ was assigned to the $\mathrm{Si}-\mathrm{O}-\mathrm{Al}$ rocking, representing the linkage between the $\left[\mathrm{SiO}_{4}\right]^{4-}$ and $\left[\mathrm{AlO}_{4}\right]^{5-}$ tetrahedral units. The appearance of a peak around $570-520 \mathrm{~cm}^{-1}$ suggested that some $\mathrm{Al}_{2} \mathrm{O}_{3}$ existed as an $\left[\mathrm{AlO}_{6}\right]^{9-}$ octahedral units.

Figure 6 shows the FTIR transmittance of the slag with a constant $\mathrm{Al}_{2} \mathrm{O}_{3}$ concentration of $12 \%$ and $18 \%$ at different $\mathrm{MgO}$ contents. As can be noted, the center of the band for the $\left[\mathrm{SiO}_{4}\right]^{4-}$ tetrahedral structure shifts successively to a lower wave number region, with increasing $\mathrm{MgO}$ content at each $\mathrm{Al}_{2} \mathrm{O}_{3}$ concentration, thereby indicating that the relative amount of $\mathrm{Q}^{0}+\mathrm{Q}^{1}$ to $\mathrm{Q}^{2}+\mathrm{Q}^{3}$ increases. The change of the $\left[\mathrm{AlO}_{4}\right]^{5-}$ tetrahedral trough is almost negligible, since $\mathrm{MgO}$ content increases, but the $\mathrm{Si}-\mathrm{O}-\mathrm{Al}$ rocking peak seems to become weaker due to the lower absolute amount of $\mathrm{SiO}_{2}$. Figure 7 presents the FTIR transmittance of the slag with a constant $\mathrm{MgO}$ concentration of 10 and 12 mass\% at different $\mathrm{Al}_{2} \mathrm{O}_{3}$ contents. Obviously, as the $\mathrm{Al}_{2} \mathrm{O}_{3}$ content increases, the center of the band for $\mathrm{Si}-\mathrm{O}$ stretching vibrations in the $1200 \sim 750 \mathrm{~cm}^{-1}$ range continuously shifts to a region with higher wavenumbers, indicating that the relative amount of $\mathrm{Q}^{2}+\mathrm{Q}^{3}$ to $\mathrm{Q}^{0}+\mathrm{Q}^{1}$ increases. The asymmetric stretching vibration bands for the $\left[\mathrm{AlO}_{4}\right]^{5-}$ tetrahedral units in the $750 \sim 630 \mathrm{~cm}^{-1}$ range is not noticeably changed by increasing $\mathrm{Al}_{2} \mathrm{O}_{3}$ content. There are no peaks between $570 \sim 520 \mathrm{~cm}^{-1}$, which suggests that no $\left[\mathrm{AlO}_{6}\right]^{9-}$ octahedral units are present in the slag system.

The Raman and FTIR are complementary to each other because $\mathrm{T}-\mathrm{O}$ ( $\mathrm{T}$ represents $\mathrm{Si}, \mathrm{Al}$ and Ti atoms) bondings may be FTIR active, Raman active, or both. For instance, the Ti-O network is unidentifiable from the FTIR results [25-27]. Hence, the slag network structure is further analyzed by Raman spectroscopy, and the results of the original Raman spectra are shown in Figure 8a. As can be observed, the strong Raman bands are located at the $600 \sim 1100 \mathrm{~cm}^{-1}$ ranges in the entire Raman spectra for every slag. The relative intensity between the shoulder at $\sim 730 \mathrm{~cm}^{-1}$, the strongest peak at $\sim 800 \mathrm{~cm}^{-1}$, the peak at $\sim 860 \mathrm{~cm}^{-1}$, the shoulder at $\sim 910 \mathrm{~cm}^{-1}$, and the shoulder at $\sim 1000 \mathrm{~cm}^{-1}$ varies with changing slag compositions, where the former two are assigned to $\mathrm{O}-(\mathrm{Ti}, \mathrm{Si})-\mathrm{O}$ deformation 
vibrations in sheet units and $\mathrm{Ti}-\mathrm{O}$ stretching vibrations in $\left[\mathrm{TiO}_{4}\right]^{4-}$ monomers, and the latter three are identified as silicate structural units $\mathrm{Q}^{0}, \mathrm{Q}^{1}$, and $\mathrm{Q}^{2}$, respectively, according to previous work [28-34]. The Raman bands that correspond to Al-O stretching vibrations $[24,35,36]$ at $530 \sim 610 \mathrm{~cm}^{-1}$ do not change significantly, similar to FTIR results.

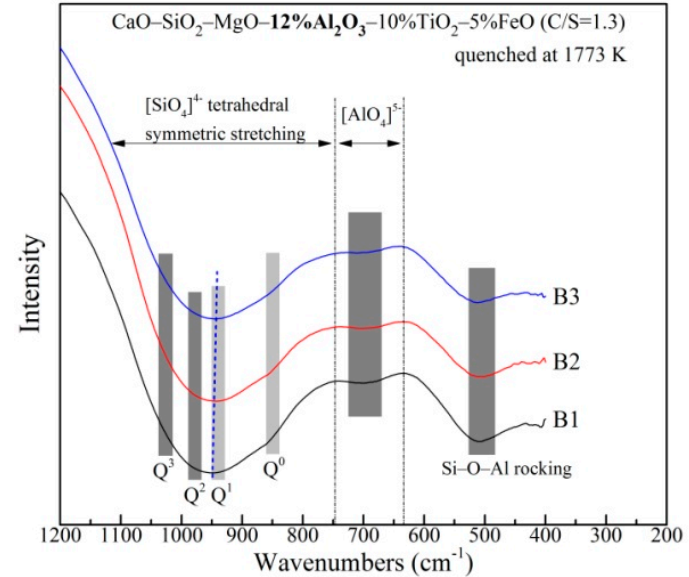

(a)

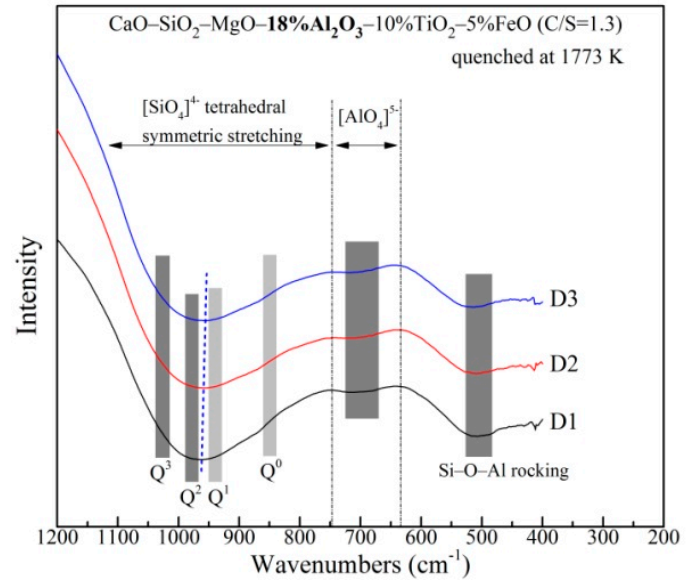

(b)

Figure 6. FTIR results of the slag with varying $\mathrm{MgO}$ content, with $\mathrm{Al}_{2} \mathrm{O}_{3}$ content of (a) 12 mass $\%$ and (b) 18 mass $\%$.

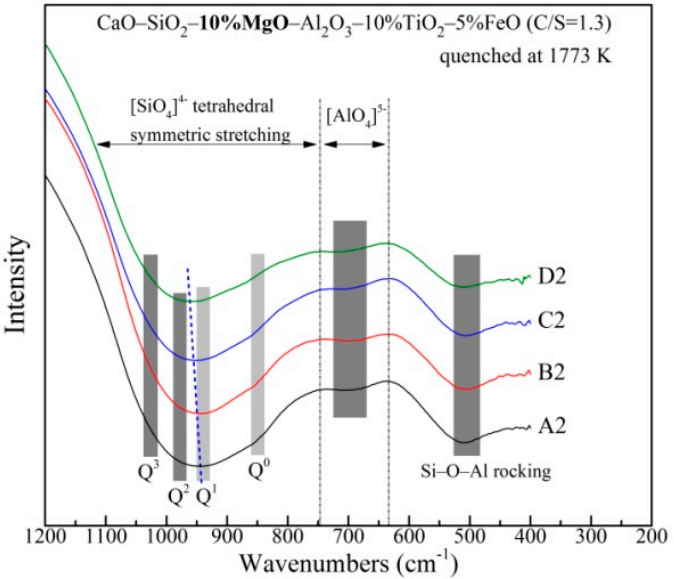

(a)

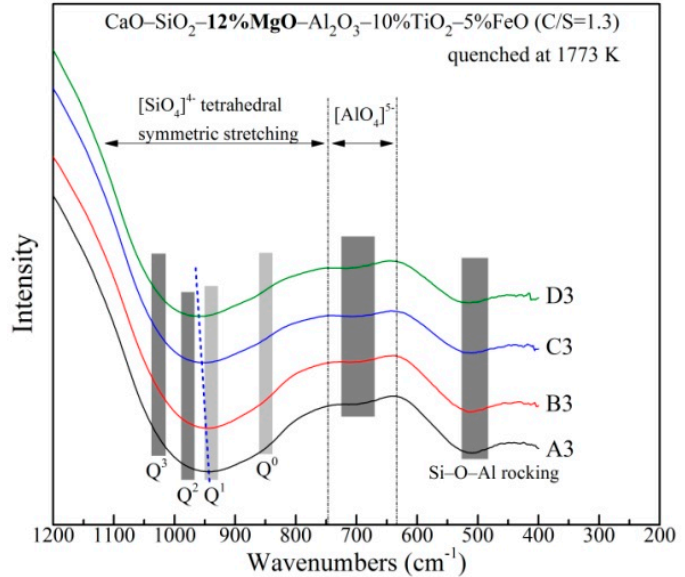

(b)

Figure 7. FTIR results of the slag with varying $\mathrm{Al}_{2} \mathrm{O}_{3}$ content, with $\mathrm{MgO}$ content of (a) $10 \mathrm{mass} \%$ and (b) 12 mass $\%$.

In order to illustrate the detailed change of the $\mathrm{Si}-\mathrm{O}$ and $\mathrm{Ti}-\mathrm{O}$ networks, the Gaussian-Deconvolution method was employed by assuming contributions from the structural units of $\mathrm{O}-(\mathrm{Ti}, \mathrm{Si})-\mathrm{O},\left[\mathrm{TiO}_{4}\right]^{4-}, \mathrm{Q}^{0}, \mathrm{Q}^{1}$, and $\mathrm{Q}^{2}$ to deconvolute the Raman spectra bands between 600 and $1100 \mathrm{~cm}^{-1}$ with a minimum correlation coefficient of 0.99 , similar to the method used by other researchers [17]. The assignments of the Raman shift for various structural units are listed in Table 3. A typical deconvolution of the Raman spectra is shown in Figure 8b through this approach. In this way, the area ratios of $\mathrm{O}-(\mathrm{Ti}, \mathrm{Si})-\mathrm{O},\left[\mathrm{TiO}_{4}\right]^{4-}, \mathrm{Q}^{0}, \mathrm{Q}^{1}$, and $\mathrm{Q}^{2}$ can be ascertained. Based on the obtained peak area ratios and the Raman scattering coefficient of $\mathrm{Q}^{n}$, the mole fractions of $\mathrm{Q}^{n}$ could be calculated by the specified equation $[13,37]$. Generally, the average amount of non-bridging oxygen (NBO/Si) is used to explain the $\mathrm{Si}-\mathrm{O}$ network by referring to previous studies [38,39]. NBO/Si is calculated by the mole fractions of $\mathrm{Q}^{n}$ multiplied by the amount of its non-bridging oxygen, where lower NBO/Si implies a more polymerized $\mathrm{Si}-\mathrm{O}$ network structure. The effects of $\mathrm{MgO}$ and $\mathrm{Al}_{2} \mathrm{O}_{3}$ on $\mathrm{O}-(\mathrm{Ti}, \mathrm{Si})-\mathrm{O},\left[\mathrm{TiO}_{4}\right]^{4-}$ 
and $\mathrm{NBO} / \mathrm{Si}$ can be observed in Figures 9 and 10. When $\mathrm{MgO}$ content increases at a fixed $\mathrm{Al}_{2} \mathrm{O}_{3}$ concentration, the amount of $\mathrm{O}-(\mathrm{Ti}, \mathrm{Si})-\mathrm{O}$ decreases and the amount of $\left[\mathrm{TiO}_{4}\right]^{4-}$ increases. Meanwhile, $\mathrm{NBO} / \mathrm{Si}$ trends upward by increasing $\mathrm{MgO}$. On the other hand, by increasing $\mathrm{Al}_{2} \mathrm{O}_{3}$ content at a fixed $\mathrm{MgO}$ concentration, an increased amount of $\mathrm{O}-(\mathrm{Ti}, \mathrm{Si})-\mathrm{O}$ and a decreased amount of $\left[\mathrm{TiO}_{4}\right]^{4-}$ and lower $\mathrm{NBO}$ are observed with higher $\mathrm{Al}_{2} \mathrm{O}_{3}$ content.

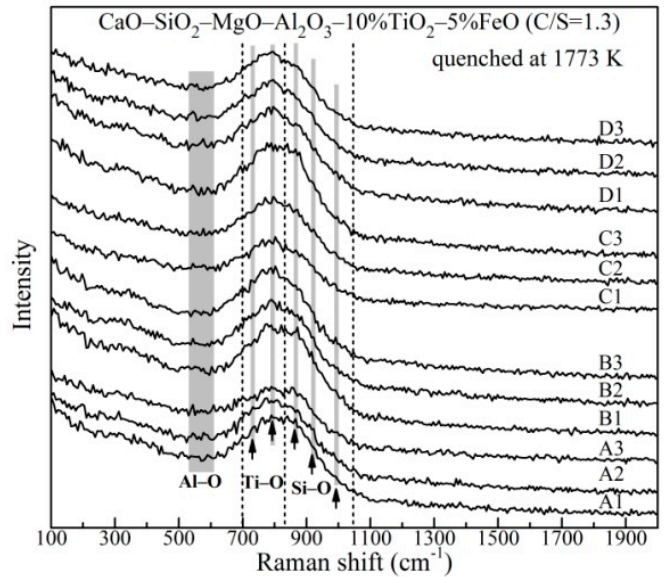

(a)

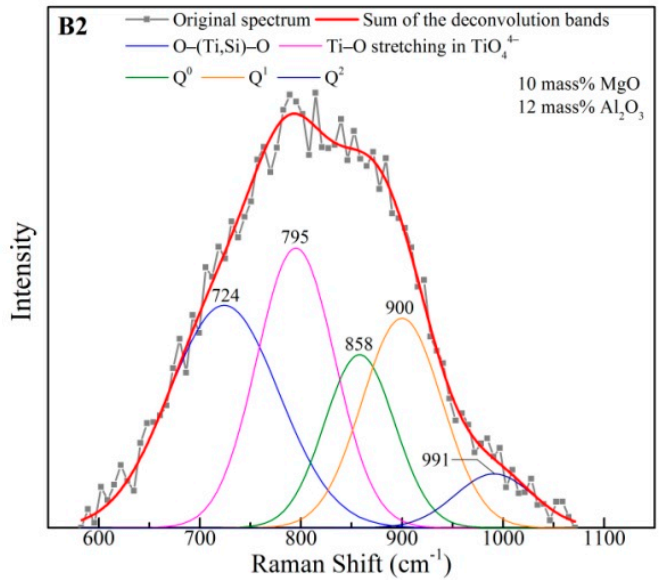

(b)

Figure 8. (a) Original Raman spectra of the rapidly quenched slag samples from $1773 \mathrm{~K}$; (b) the typical deconvolution of the Raman spectra for B2.

Table 3. Assignment of Raman peaks in the spectra of the present slag system.

\begin{tabular}{ccc}
\hline Raman Shift $\mathbf{( c m}^{\mathbf{- 1}} \mathbf{)}$ & Raman Assignments & References \\
\hline $710 \sim 730$ & $\mathrm{O}-(\mathrm{Ti}, \mathrm{Si})-\mathrm{O}$ deformation vibrations in sheet units & {$[28,29]$} \\
$790 \sim 810$ & $\mathrm{Ti}-\mathrm{O}$ stretching vibrations in $\left[\mathrm{TiO}_{4}\right]^{4-}$ monomers & {$[28,30,31]$} \\
$900 \sim 920$ & $\mathrm{Q}^{0}$ & {$[32,33]$} \\
$840 \sim 860$ & $\mathrm{Q}^{1}$ & {$[32,33]$} \\
$980 \sim 1000$ & $\mathrm{Q}^{2}$ & {$[32-34]$} \\
\hline
\end{tabular}

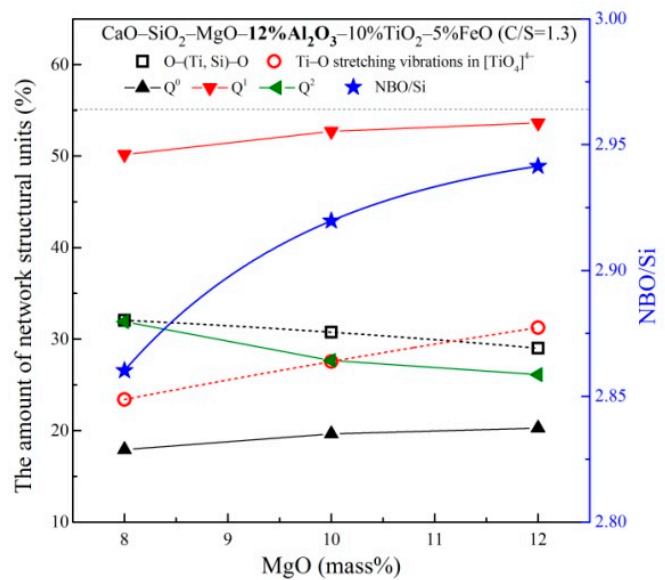

(a)

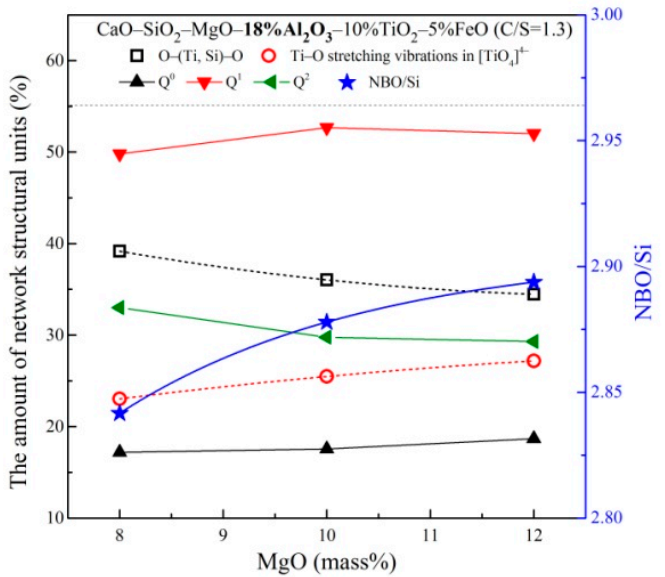

(b)

Figure 9. Abundance of the structural units with varying $\mathrm{MgO}$ content at fixed $\mathrm{Al}_{2} \mathrm{O}_{3}$ concentrations of (a) 12 mass \% and (b) 18 mass \%. 


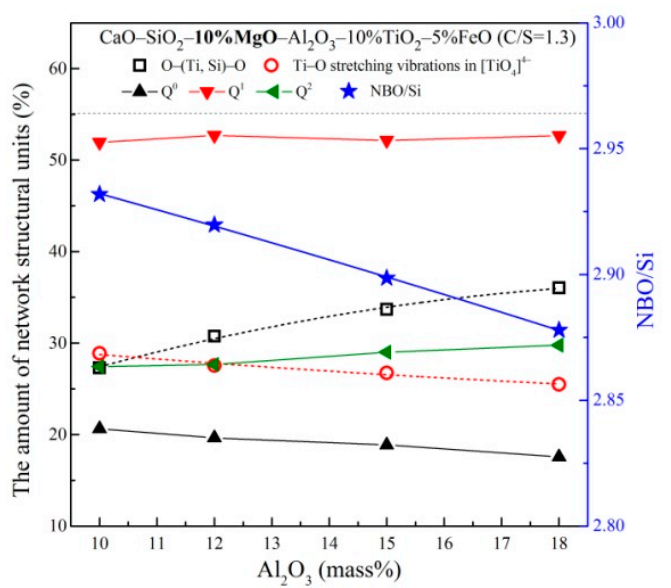

(a)

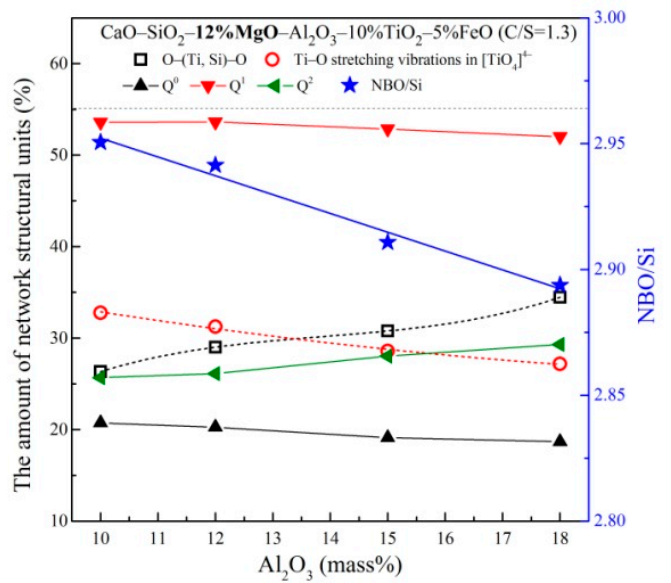

(b)

Figure 10. Abundance of the structural units with varying $\mathrm{Al}_{2} \mathrm{O}_{3}$ content at fixed $\mathrm{MgO}$ concentrations of (a) 10 mass $\%$ and (b) 12 mass $\%$.

\section{Discussion}

\subsection{Correlation Between Viscosity and Network Structure}

For the $\mathrm{CaO}-\mathrm{MgO}-\mathrm{Al}_{2} \mathrm{O}_{3}-\mathrm{SiO}_{2}-10 \% \mathrm{TiO}_{2}-5 \% \mathrm{FeO}$ slag, it was noted that the center of the $\left[\mathrm{SiO}_{4}\right]^{4-}$ tetrahedral stretching bands is positioned between the characteristic peaks of $\mathrm{Q}^{1}$ and $\mathrm{Q}^{2}$ based on the FTIR results. This is in accordance with the Raman results, which show that (1) no $Q^{3}$ units are found, (2) the mole fraction of $\mathrm{Q}^{1}$ is more than $50 \%$, and (3) the amount of $\mathrm{Q}^{0}, \mathrm{Q}^{1}$, and $\mathrm{Q}^{2}$ is in the order of $\mathrm{Q}^{1}>\mathrm{Q}^{2}>\mathrm{Q}^{0}$. A reasonable structural interpretation should be considered. The total amount of basic oxides is perhaps too high to make an $\mathrm{Si}-\mathrm{O}$ network form large and complex polymers, such as $\mathrm{Q}^{3}$. Therefore, $\mathrm{Q}^{0}, \mathrm{Q}^{1}$, and $\mathrm{Q}^{2}$ constitute the Si-O network in the present slag.

As $\mathrm{MgO}$ content increases at a fixed $\mathrm{Al}_{2} \mathrm{O}_{3}$ concentration, more free $\mathrm{O}^{2-}$, originating from $\mathrm{MgO}$ dissociation, is introduced to the slag so that $\mathrm{Q}^{2}$ is modified to $\mathrm{Q}^{0}$ and $\mathrm{Q}^{1}$. Both the negative center shift of the $\left[\mathrm{SiO}_{4}\right]^{4-}$ tetrahedral stretching bands in Figure 6 and the increase of NBO in Figure 9 prove that the $\mathrm{Si}-\mathrm{O}$ network is depolymerized. As for the $\mathrm{Ti}-\mathrm{O}$ network, $\mathrm{O}-(\mathrm{Ti}, \mathrm{Si})-\mathrm{O}$ deformation in the sheet unit is considered to be a complex structural unit $[28,39]$, whereas $\left[\mathrm{TiO}_{4}\right]^{4-}$ is a short range ordered simple unit $[25,40]$. The Ti-O network is believed to be simplified with higher MgO content due to its less complex and simpler Ti-O structures, as proven in Figure 9. From the FTIR spectra in Figures 6 and 7 , the absence of $\left[\mathrm{AlO}_{6}\right]^{9-}$ confirms that $\mathrm{Al}_{2} \mathrm{O}_{3}$ serves only as a network former in the present slags. The addition of $\mathrm{Al}_{2} \mathrm{O}_{3}$ consumes free $\mathrm{O}^{2-}$ so that the $\mathrm{Si}-\mathrm{O}$ and Ti-O network's structural units show opposite variation tendencies compared to the effects of $\mathrm{MgO}$. The $\mathrm{Si}-\mathrm{O}$ and Ti-O networks are more complex, as expected with increasing $\mathrm{Al}_{2} \mathrm{O}_{3}$ content. The $\left[\mathrm{AlO}_{4}\right]^{5-}$ tetrahedral vibration is found to be seldom changed in FTIR, which can also be observed in the Raman results depicted in Figure 8a. It seems that both $\mathrm{MgO}$ and $\mathrm{Al}_{2} \mathrm{O}_{3}$ affect the $\mathrm{Al}-\mathrm{O}$ network little and instead prefer to modify the $\mathrm{Si}-\mathrm{O}$ and Ti-O networks. This preference could be explained in two ways. On the one hand, the Si-O network is dominant and the first to be affected due to the large absolute amount of $\mathrm{SiO}_{2}$ in the slag. On the other hand, $\mathrm{Ti}-\mathrm{O}$ bonding is weaker than that of $\mathrm{Al}-\mathrm{O}$ and $\mathrm{Si}-\mathrm{O}$, which allows the Ti-O network to be modified relatively easy. Additionally, the FTIR trough at $\sim 500 \mathrm{~cm}^{-1}$ becomes shallower, corresponding to the decreased viscosity from $15 \%$ to $18 \% \mathrm{Al}_{2} \mathrm{O}_{3}$ for the $8 \% \mathrm{MgO}$ slags [13]. For the present slags with $10 \%$ and $12 \% \mathrm{MgO}$ in Figure 6, the trough is also dampened while the corresponding viscosity increases from $15 \%$ to $18 \% \mathrm{Al}_{2} \mathrm{O}_{3}$. The reasons for these results can be explained as follows. A higher $\mathrm{MgO}$ content leads to a higher depolymerization of slag. The role of $\mathrm{Al}_{2} \mathrm{O}_{3}$ on slag polymerization is likely to be more dominant than the weaker linkage between the $\left[\mathrm{SiO}_{4}\right]^{4-}$ and $\left[\mathrm{AlO}_{4}\right]^{5-}$ tetrahedral units for the slags with higher $\mathrm{MgO}$ content. Summing 
up the above discussion, when $\mathrm{MgO}$ or $\mathrm{Al}_{2} \mathrm{O}_{3}$ content increases, the $\mathrm{Si}-\mathrm{O}$ and Ti-O networks are both depolymerized or polymerized, which explains the general decrease or increase of the viscosity and $E_{\eta}$ in the current study.

\subsection{Interpretation of the Unusual Viscosity}

The slag with $10 \% \mathrm{MgO}$ and $12 \% \mathrm{Al}_{2} \mathrm{O}_{3}$ is unusual as it has the lowest viscosity and $E_{\eta}$, contributing to the fact that the viscosity goes up by increasing $\mathrm{MgO}$ from $10 \%$ to $12 \%$ (Figure $3 \mathrm{~b}$ ) and the viscosity decreases by increasing $\mathrm{Al}_{2} \mathrm{O}_{3}$ from $10 \%$ to $12 \%$ (Figure $4 \mathrm{a}$ ). These phenomena cannot be explained only in terms of a change in network structure, depolymerization, or polymerization as a result of the basic or acid behavior of $\mathrm{MgO}$ or $\mathrm{Al}_{2} \mathrm{O}_{3}$. There must be other factors that affect this viscous behavior.

A similar phenomenon was observed by Mudersbach et al. [41], Kim et al. [42], and Sun et al. [43], which showed that the slag viscosity exhibited a minimum value by increasing $\mathrm{MgO}$ content with a fixed $\mathrm{C} / \mathrm{S}$ and $\mathrm{Al}_{2} \mathrm{O}_{3}$ content, even though the slag was fully liquid. In Zhang's review [44], MgO was proposed to have a relatively high stability and be more effective in increasing viscosity due to its high melting point. There is a common viewpoint that the viscosity was occasionally influenced by the change in the structure of the ion arrangements in liquids corresponding to the changes in the primary phases from the melts [42,45] led by varying chemical composition.

Because the experimental phase diagram of the $\mathrm{CaO}-\mathrm{SiO}_{2}-\mathrm{MgO}-\mathrm{Al}_{2} \mathrm{O}_{3}-\mathrm{TiO}_{2}-\mathrm{FeO}$ system has yet to be reported, the phase diagrams of the $\mathrm{CaO}-\mathrm{SiO}_{2}-\mathrm{MgO}-\mathrm{Al}_{2} \mathrm{O}_{3}-10 \mathrm{mass} \% \mathrm{TiO}_{2}-5 \mathrm{mass} \% \mathrm{FeO}$ slag system are calculated by Factsage (Version 7.2, CRCT ThermFact Inc., Montreal, QC, Canada) [46] and shown in Figure 11. The slag composition is marked with solid black circles. The values presented in the vicinity of the solid circle are the liquidus temperatures of some slag samples. As can be seen, the slag composed of $10 \% \mathrm{MgO}$ and $12 \% \mathrm{Al}_{2} \mathrm{O}_{3}$ exists near the eutectic line of the perovskite and spinel. The melting points of perovskite and spinel are 2243 and $2523 \mathrm{~K}$, respectively. At a fixed $12 \% \mathrm{Al}_{2} \mathrm{O}_{3}$, and by increasing $\mathrm{MgO}$ content from $8 \%$ to $12 \%(\mathrm{~B} 1 \rightarrow \mathrm{B} 2 \rightarrow \mathrm{B} 3)$, the slag composition in the crystalline region of the perovskite moves toward the eutectic line and then crosses the eutectic line, reaching the thermostable spinel region. For the slag samples with a fixed $10 \% \mathrm{MgO}$, and with additions of $\mathrm{Al}_{2} \mathrm{O}_{3}$ from $10 \%$ to $15 \%(\mathrm{~A} 2 \rightarrow \mathrm{B} 2 \rightarrow \mathrm{C} 2 \rightarrow \mathrm{D} 2)$, similar trends are noted. When the slag is located in a higher-temperature stable spinel phase region, the arrangement of ions in the liquid approaches and resembles the structure of the solid spinel crystal, and ionic interactions tends to be stronger, resulting in difficulties running the flow units and a higher viscosity. This phenomenon, then, would be a reason for the increased viscosity in Figure 3b. For the effect of $\mathrm{Al}_{2} \mathrm{O}_{3}$, Park et al. reported that the viscosity of $\mathrm{FeO}-\mathrm{Al}_{2} \mathrm{O}_{3}-\mathrm{SiO}_{2}$ slag initially decreased and subsequently increased with increasing $\mathrm{Al}_{2} \mathrm{O}_{3}$ content at a fixed $\mathrm{Fe} / \mathrm{SiO}_{2}$ [47]. Superheat has been suggested to be the difference in the experimental and liquidus temperatures and can exert an impact on viscosity. By increasing the $\mathrm{Al}_{2} \mathrm{O}_{3}$ content of the slag composed of $10 \% \mathrm{MgO}$ and $12 \% \mathrm{Al}_{2} \mathrm{O}_{3}(\mathrm{~A} 2 \rightarrow \mathrm{B} 2)$, the liquidus temperature decreases, and the superheat temperature increases correspondingly. Both the minimum viscosity and the maximum superheat temperature appear at the $10 \% \mathrm{MgO}$ and $12 \% \mathrm{Al}_{2} \mathrm{O}_{3}$ composition point, which is close to the eutectic line. This could be the reason for the decreased slag viscosity in Figure 4a. Additionally, the viscosity variation pattern from $10 \%$ to $12 \% \mathrm{MgO}$ for $15 \% \mathrm{Al}_{2} \mathrm{O}_{3}$ slag is a bit odd. The $\mathrm{MgO}$ content in excess of $10 \%$ increases the liquidus temperature, likely causing liquid contraction and leading to the aforementioned phenomenon. 


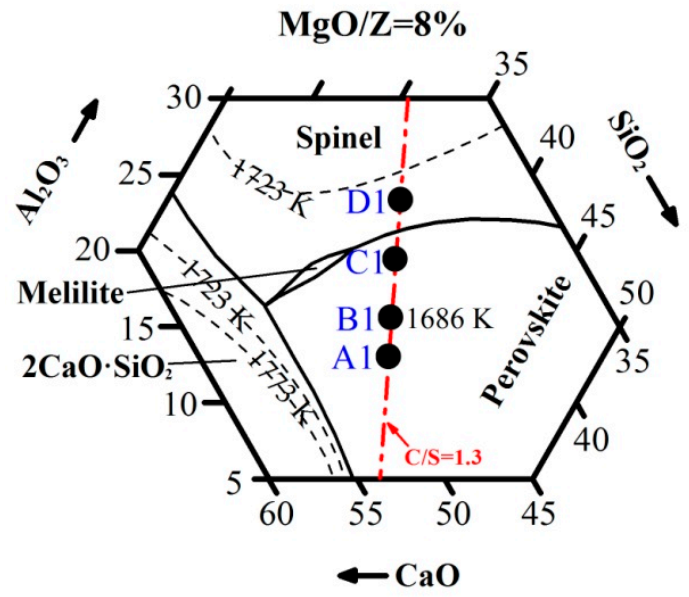

(a)

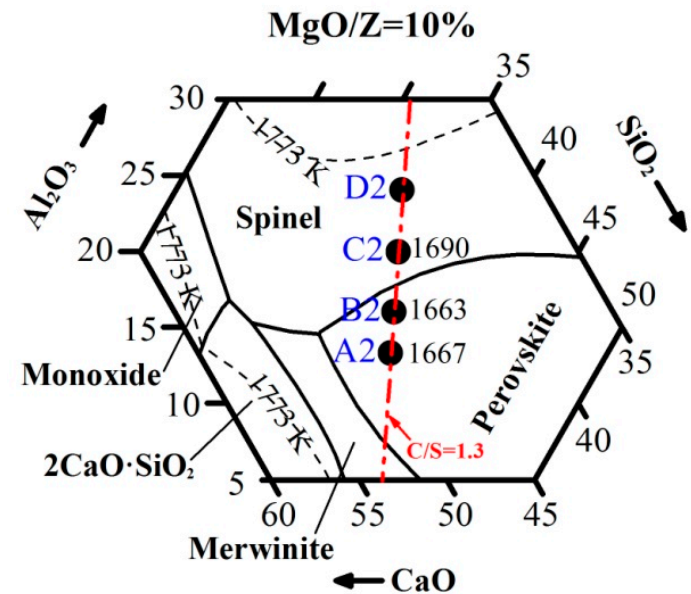

(b)

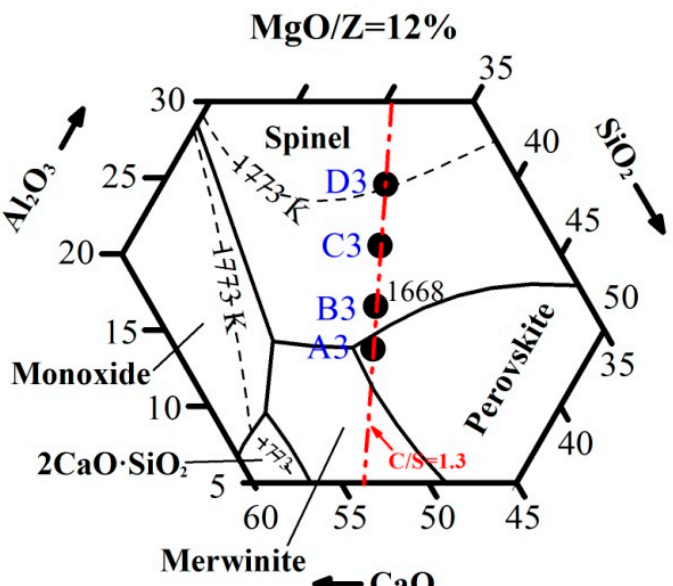

(c)

Figure 11. Phase diagrams of the $\mathrm{CaO}-\mathrm{MgO}-\mathrm{Al}_{2} \mathrm{O}_{3}-\mathrm{SiO}_{2}-10$ mass $\% \mathrm{TiO}_{2}-5$ mass $\%$ FeO slag system calculated by Factsage $7.2\left(\mathrm{TiO}_{2} / \mathrm{Z}=10 \%, \mathrm{FeO} / \mathrm{Z}=5 \%, \mathrm{Z}=\mathrm{CaO}+\mathrm{SiO}_{2}+\mathrm{MgO}+\mathrm{Al}_{2} \mathrm{O}_{3}+\mathrm{TiO}_{2}+\mathrm{FeO}\right.$, mass fraction), (a) 8 mass $\% \mathrm{MgO}$; (b) 10 mass $\% \mathrm{MgO}$; (c) 12 mass $\% \mathrm{MgO}$.

\section{Conclusions}

The $\mathrm{CaO}-\mathrm{SiO}_{2}-\mathrm{MgO}-\mathrm{Al}_{2} \mathrm{O}_{3}-10$ mass $\% \mathrm{TiO}_{2}-5$ mass $\% \mathrm{FeO}(\mathrm{C} / \mathrm{S}=1.3)$ slag was investigated through viscosity measurements combined with FTIR and Raman spectroscopic analyses to provide insight into the roles of $\mathrm{MgO}$ and $\mathrm{Al}_{2} \mathrm{O}_{3}$ on the viscous and structural behavior of Ti-bearing primary slag. The main findings are summarized as follows.

(1) In this study, the viscosity trend correlates well with the variation of activation energy for slags with changing $\mathrm{MgO}$ and $\mathrm{Al}_{2} \mathrm{O}_{3}$ content. The usual viscous behavior ( $\mathrm{MgO}$ decreases and $\mathrm{Al}_{2} \mathrm{O}_{3}$ increases viscosity) can be explained by a change of the network structure.

(2) FTIR and Raman analyses show that $\mathrm{Si}-\mathrm{O}$ and $\mathrm{Ti}-\mathrm{O}$ networks are depolymerized as $\mathrm{MgO}$ increases, presenting as a modification of $\mathrm{Q}^{2}$ to $\mathrm{Q}^{0}$ and $\mathrm{Q}^{1}$ and less complex Ti-O structural units, respectively. Increased $\mathrm{Al}_{2} \mathrm{O}_{3}$ contributes opposite variation tendencies. The addition of $\mathrm{MgO}$ and $\mathrm{Al}_{2} \mathrm{O}_{3}$ prefers to modify $\mathrm{Si}-\mathrm{O}$ and Ti-O networks, likely due to the predominance of $\mathrm{SiO}_{2}$ and weak Ti-O bonding.

(3) The unexpected viscous behaviors ( $\mathrm{MgO}$ increases and $\mathrm{Al}_{2} \mathrm{O}_{3}$ decreases viscosity) could be interpreted by changes in ions' arrangement structures in liquid, corresponding to the changes of the primary equilibrium phase region and the variation of the difference between the experimental and liquidus temperatures, respectively. 
Author Contributions: Conceptualization, S.S. and Q.W.; methodology, T.L. and C.S.; software, T.L.; validation, C.S.; formal analysis, T.L.; investigation, T.L.; resources, Q.W.; writing-original draft preparation, T.L.; writing-review and editing, C.S. and S.S.; supervision, Q.W.; project administration, Q.W.; funding acquisition, S.S. and Q.W.

Funding: This research was funded by The Rio Tinto-USTL (University of Science and Technology Liaoning) Joint Research Project and Liaoning Province Natural Fund Guidance Plan Project (20180550599).

Acknowledgments: We gratefully express our appreciation to Rio Tinto through The Rio Tinto-USTL (University of Science and Technology Liaoning) Joint Research Project and Liaoning Province Natural Fund Guidance Plan Project (20180550599) for supporting this work.

Conflicts of Interest: The authors declare no conflict of interest.

\section{References}

1. Li, Z.S.; Davis, C. Ironmaking and Steelmaking. Metals 2019, 9, 525. [CrossRef]

2. Zhou, X.L.; Luo, Y.H.; Chen, T.J.; Zhu, D.Q. Enhancing the reduction of high-aluminum iron ore by synergistic reducing with high-manganese iron ore. Metals 2019, 9, 15. [CrossRef]

3. Feng, C.; Chu, M.S.; Tang, J.; Tang, Y.T.; Liu, Z.G. Effect of $\mathrm{CaO} / \mathrm{SiO}_{2}$ and $\mathrm{Al}_{2} \mathrm{O}_{3}$ on viscous behaviors of the titanium-bearing blast furnace slag. Steel Res. Int. 2016, 87, 1274-1283. [CrossRef]

4. Yan, Z.M.; Lv, X.W.; Zhang, J.; Qin, Y.; Bai, C.G. Influence of $\mathrm{MgO}, \mathrm{Al}_{2} \mathrm{O}_{3}$ and $\mathrm{CaO} / \mathrm{SiO}_{2}$ on the viscosity of blast furnace type slag with high $\mathrm{Al}_{2} \mathrm{O}_{3}$ and $5 \mathrm{wt} \% \mathrm{TiO}_{2}$. Can. Metall. Quart. 2016, 55, 186-194. [CrossRef]

5. Bian, L.T.; Gao, Y.H. Influence of $\mathrm{Al}_{2} \mathrm{O}_{3}, \mathrm{CaO} / \mathrm{SiO}_{2}$, and $\mathrm{B}_{2} \mathrm{O}_{3}$ on viscous behavior of high alumina and medium titania blast furnace slag. J. Chem. 2017, 2017, 6895928. [CrossRef]

6. Zhou, J.; Tang, D.W.; Wang, H.F.; Xu, H.X. Research of influence of $\mathrm{Al}_{2} \mathrm{O}_{3}$ on metallurgical properties for the medium titanium slag. J. Mater. Metall. 2014, 13, 6-10, In Chinese.

7. Feng, C.; Chu, M.S.; Tang, J.; Qin, J.; Li, F.; Liu, Z.G. Effects of $\mathrm{MgO}$ and $\mathrm{TiO}_{2}$ on the viscous behaviors and phase compositions of titanium-bearing slag. Int. J. Miner. Metall. Mater. 2016, 23, 868-880. [CrossRef]

8. Liang, H.L.; Chu, M.S.; Feng, C.; Tang, J.; Liu, Z.G.; Wang, W.P. Optimisation study and affecting mechanism of $\mathrm{CaO} / \mathrm{SiO}_{2}$ and $\mathrm{MgO}$ on viscous behaviours of titanium-bearing blast furnace slag. Ironmak. Steelmak. 2018, 45. [CrossRef]

9. Tang, Z.H.; Ding, X.Y.; Dong, Y.; Liu, C.H.; Wei, G. Influence of $w(\mathrm{MgO})$ on viscous flow property of high Ti-containing blast furnace slag. Chin. J. Mater. Res. 2016, 30, 443-447. (In Chinese) [CrossRef]

10. Brawer, S.A.; White, W.B. Raman spectroscopic investigation of the structure of silicate glasses (II). soda-alkaline earth-alumina ternary and quaternary glasses. J. Non-Cryst. Solids. 1977, 23, 261-278. [CrossRef]

11. Mysen, B.O.; Virgo, D.; Kushiro, I. The structural role of aluminium in silicate melts-A Raman spectroscopic study at 1 atmosphere. Am. Mineral. 1981, 66, 678-701.

12. Li, T.L.; Sun, C.Y.; Lan, D.; Song, J.; Song, S.; Wang, Q. Effect of mineral elements migration on softening-melting properties of Ti-bearing high basicity sinter. ISIJ Int. 2019, 59, 245-252. [CrossRef]

13. Li, T.L.; Sun, C.Y.; Song, S.; Wang, Q. Influences of $\mathrm{Al}_{2} \mathrm{O}_{3}$ and $\mathrm{TiO}_{2}$ content on viscosity and structure of $\mathrm{CaO}-8 \% \mathrm{MgO}-\mathrm{Al}_{2} \mathrm{O}_{3}-\mathrm{SiO}_{2}-\mathrm{TiO}_{2}-5 \% \mathrm{FeO}$ blast furnace primary slag. Metals 2019, 9, 743. [CrossRef]

14. Park, J.H.; Min, D.J.; Song, H.S. FT-IR spectroscopic study on structure of $\mathrm{CaO}-\mathrm{SiO}_{2}$ and $\mathrm{CaO}-\mathrm{SiO}_{2}-\mathrm{CaF}_{2}$ slags. ISIJ Int. 2002, 42, 344-351. [CrossRef]

15. Park, J.H.; Min, D.J.; Song, H.S. Structural investigation of $\mathrm{CaO}-\mathrm{Al}_{2} \mathrm{O}_{3}$ and $\mathrm{CaO}-\mathrm{Al}_{2} \mathrm{O}_{3}-\mathrm{CaF}_{2}$ slags via Fourier Transform Infrared Spectra. ISIJ Int. 2002, 42, 38-43. [CrossRef]

16. Kim, J.R.; Lee, Y.S.; Min, D.J.; Jung, S.M.; Yi, S.H. Influence of $\mathrm{MgO}$ and $\mathrm{Al}_{2} \mathrm{O}_{3}$ contents on viscosity of blast furnace type slags containing FeO. ISIJ Int. 2004, 44, 1291-1297. [CrossRef]

17. Kim, G.H.; Kim, C.S.; Sohn, I. Viscous behavior of alumina rich calcium-silicate based mold fluxes and its correlation to the melt structure. ISIJ Int. 2013, 53, 170-176. [CrossRef]

18. Song, M.; Shu, Q.F.; Du, S.C. Viscosities of the quaternary $\mathrm{Al}_{2} \mathrm{O}_{3}-\mathrm{CaO}-\mathrm{MgO}-\mathrm{SiO}_{2}$ slags. Steel Res. Int. 2011, 82, 260-268. [CrossRef]

19. Li, Z.R.; You, X.C.; Li, M.; Wang, Q.; He, S.P.; Wang, Q.Q. Effect of substituting $\mathrm{CaO}$ with $\mathrm{BaO}$ and $\mathrm{CaO} / \mathrm{Al}_{2} \mathrm{O}_{3}$ ratio on the viscosity of $\mathrm{CaO}-\mathrm{BaO}-\mathrm{Al}_{2} \mathrm{O}_{3}-\mathrm{CaF}_{2}-\mathrm{Li}_{2} \mathrm{O}$ mold flux system. Metals 2019, 9, 142. [CrossRef]

20. Hu, K.; Lv, X.W.; Li, S.P.; Lv, W.; Song, B.; Han, K.X. Viscosity of $\mathrm{TiO}_{2}-\mathrm{FeO}-\mathrm{Ti}_{2} \mathrm{O}_{3}-\mathrm{SiO}_{2}-\mathrm{MgO}-\mathrm{CaO}-\mathrm{Al}_{2} \mathrm{O}_{3}$ for high-titania slag smelting process. Metall. Mater. Trans. B 2018, 49, 1963-1973. [CrossRef] 
21. Stevels, J.M. Glass as a high polymer. Verres Refract. 1953, 7, 91-104.

22. Stevels, J.M. Networks in glasses and other polymers. Glass Ind. 1954, 35, 657-662.

23. Min, D.J.; Tsukihashi, F. Recent advances in understanding physical properties of metallurgical slags. Met. Mater. Int. 2017, 23, 1-19. [CrossRef]

24. Shen, X.; Chen, M.; Wang, N.; Wang, D. Viscosity property and melt structure of CaO-MgO-SiO $-\mathrm{Al}_{2} \mathrm{O}_{3}-\mathrm{FeO}$ slag system. ISIJ Int. 2019, 59, 9-15. [CrossRef]

25. Kim, J.B.; Sohn, I. Effect of $\mathrm{SiO}_{2} / \mathrm{Al}_{2} \mathrm{O}_{3}$ and $\mathrm{TiO}_{2} / \mathrm{SiO}_{2}$ ratios on the viscosity and structure of the $\mathrm{TiO}_{2}-\mathrm{MnO}-\mathrm{SiO}_{2}-\mathrm{Al}_{2} \mathrm{O}_{3}$ welding flux system. ISIJ Int. 2014, 54, 2050-2058. [CrossRef]

26. Park, H.; Park, J.Y.; Kim, G.H.; Sohn, I. Effect of $\mathrm{TiO}_{2}$ on the viscosity and slag structure in blast furnace type slags. Steel Res. Int. 2012, 83, 150-156. [CrossRef]

27. Jiao, K.X.; Zhang, J.L.; Wang, Z.Y.; Chen, C.L.; Liu, Y.X. Effect of $\mathrm{TiO}_{2}$ and $\mathrm{FeO}$ on the viscosity and structure of blast furnace primary slags. Steel Res. Int. 2017, 88, 1600296. [CrossRef]

28. Mysen, B.O.; Ryerson, F.J.; Virgo, D. The influence of $\mathrm{TiO}_{2}$ on the structure and derivative properties of silicate melts. Am. Mineral. 1980, 65, 1150-1165.

29. Bihuniak, P.P.; Condrate, R.A. Structures, spectra and related properties of group IVB-doped vitreous silica. J. Non-Cryst. Solids. 1981, 44, 331-343. [CrossRef]

30. Zhen, Y.L.; Zhang, G.H.; Chou, K.C. Influence of $\mathrm{Al}_{2} \mathrm{O}_{3} / \mathrm{TiO}_{2}$ ratio on viscosities and structure of $\mathrm{CaO}-\mathrm{MgO}-\mathrm{Al}_{2} \mathrm{O}_{3}-\mathrm{SiO}_{2}-\mathrm{TiO}_{2}$ melts. ISIJ Int. 2014, 54, 985-989. [CrossRef]

31. Qiu, G.B.; Chen, L.; Zhu, J.Y.; Lv, X.W.; Bai, C.G. Effect of $\mathrm{Cr}_{2} \mathrm{O}_{3}$ addition on viscosity and structure of Ti-bearing blast furnace slag. ISIJ Int. 2015, 53, 1367-1376. [CrossRef]

32. Mysen, B.O.; Virgo, D.; Seifert, F.A. Relationships between properties and structure of aluminosilicate melts. Am. Mineral. 1985, 70, 88-105.

33. Mysen, B.O.; Virgo, D.; Scarfe, C.M.; Cronin, D.J. Viscosity and structure of iron-and aluminum-bearing calcium silicate melts at $1 \mathrm{~atm}$. Am. Mineral. 1985, 70, 487-498.

34. Sun, Y.Q.; Zhang, Z.T.; Liu, L.L.; Wang, X.D. FTIR, Raman and NMR investigation of CaO-SiO $2-\mathrm{P}_{2} \mathrm{O}_{5}$ and $\mathrm{CaO}-\mathrm{SiO}_{2}-\mathrm{TiO}_{2}-\mathrm{P}_{2} \mathrm{O}_{5}$ glasses. J. Non-Cryst. Solids. 2015, 420, 26-33. [CrossRef]

35. Sun, Y.Q.; Wang, H.; Zhang, Z.T. Understanding the relationship between structure and thermophysical properties of $\mathrm{CaO}-\mathrm{SiO}_{2}-\mathrm{MgO}-\mathrm{Al}_{2} \mathrm{O}_{3}$ molten slags. Metall. Mater. Trans. B 2018, 49, 677-687. [CrossRef]

36. Shi, C.B.; Zheng, D.L.; Shin, S.H.; Li, J.; Cho, J.W. Effect of $\mathrm{TiO}_{2}$ on the viscosity and structure of low-fluoride slag used for electroslag remelting of Ti-containing steels. Int. J. Miner. Metall. Mater. 2017, 24, 18-24. [CrossRef]

37. Sun, Y.Q.; Chen, M.; Zhao, B.J. Modification of the microstructures of $\mathrm{CaO}-\mathrm{SiO}_{2}-\mathrm{Al}_{2} \mathrm{O}_{3}-\mathrm{MgO}$ slags using various minor elements. J. Non-Cryst. Solids. 2019, 515, 50-57. [CrossRef]

38. Frantza, J.D.; Mysen, B.O. Raman spectra and structure of $\mathrm{BaO}-\mathrm{SiO}_{2}, \mathrm{SrO}-\mathrm{SiO}_{2}$ and $\mathrm{CaO}-\mathrm{SiO}_{2}$ melts to $1600{ }^{\circ}$ C. Chem. Geol. 1995, 121, 155-176. [CrossRef]

39. Feng, C.; Tang, J.; Gao, L.H.; Liu, Z.G.; Chu, M.S. Effects of $\mathrm{CaO} / \mathrm{SiO}_{2}$ on viscous behaviors and structure of $\mathrm{CaO}-\mathrm{SiO}_{2}-11.00 \mathrm{wt} \% \mathrm{MgO}-11.00 \mathrm{wt} \% \mathrm{Al}_{2} \mathrm{O}_{3}-43.00 \mathrm{wt} \% \mathrm{TiO}_{2}$ slag systems. ISIJ Int. 2019, 59, 31-38. [CrossRef]

40. Mysen, B.O.; Richet, P. Silicate Glasses and Melts: Properties and Structure; Elsevier Science \& Technology: Amsterdam, The Netherlands, 2005; pp. 372-381.

41. Mudersbach, D.; Drissen, P.M.; Kühn, M.; Geiseler, J. Viscosity of slags. Steel Res. Int. 2001, 72, 86-90. [CrossRef]

42. Kim, H.; Kim, W.H.; Sohn, I.; Min, D.J. The effect of $\mathrm{MgO}$ on the viscosity of the $\mathrm{CaO}-\mathrm{SiO}_{2}-20 \mathrm{wt} \% \mathrm{Al}_{2} \mathrm{O}_{3}-\mathrm{MgO}$ slag system. Steel Res. Int. 2010, 81, 261-264. [CrossRef]

43. Sun, C.Y.; Liu, X.H.; Li, J.; Yin, X.T.; Song, S.; Wang, Q. Influence of $\mathrm{Al}_{2} \mathrm{O}_{3}$ and $\mathrm{MgO}$ on the viscosity and stability of $\mathrm{CaO}-\mathrm{MgO}-\mathrm{SiO}_{2}-\mathrm{Al}_{2} \mathrm{O}_{3}$ slags with $\mathrm{CaO} / \mathrm{SiO}_{2}=1.0$. ISIJ Int. 2017, 57, 978-982. [CrossRef]

44. Zhang, L.; Jahanshahi, S. Review and modeling of viscosity of silicate melts: Part II. viscosity of melts containing iron oxide in the $\mathrm{CaO}-\mathrm{MgO}-\mathrm{MnO}-\mathrm{FeO}-\mathrm{Fe}_{2} \mathrm{O}_{3}-\mathrm{SiO}_{2}$ system. Metall. Mater. Trans. B 1998, 29, 187-195. [CrossRef]

45. Lee, S.; Min, D.J. Viscous behavior of FeO-bearing slag melts considering structure of slag. Steel Res. Int. 2018, 89, 1-6. [CrossRef] 
46. FactSage. Available online: http://www.factsage.com (accessed on 15 February 2018).

47. Park, H.S.; Park, S.S.; Sohn, I. The viscous behavior of $\mathrm{FeO}_{t}-\mathrm{Al}_{2} \mathrm{O}_{3}-\mathrm{SiO}_{2}$ copper smelting slags. Metall. Mater. Trans. B 2011, 42, 692-699. [CrossRef] 